\title{
O Feuilleton: um gênero judaico e erótico
}

\author{
The Feuilleton: a Jewish erotic genre
}

Luis S. Krausz*

\begin{abstract}
Resumo: Este artigo aborda um gênero específico da literatura judaica europeia da passagem do século XIX para o século XX: o Feuilleton. Busca-se, nele, evidenciar as articulações existentes entre este tipo de escrita de pequenas formas, que era publicada em jornais e revistas, e a condição social de escritores judeus que, recém-chegados às metrópoles, sobre elas lançavam olhares originais, absolutamente livres, ao mesmo tempo retomando elementos da cultura judaica, dentre os quais se destaca a ênfase sobre a multiplicidade de pontos de vista. A característica central do Feuilleton é o movimento livre do olhar e da subjetividade, típico daqueles que, ao mesmo tempo, se veem inseridos e excluídos do ambiente urbano no qual se movem: autores que flanam pelas grandes metrópoles e se empenham em descrevê-la e em retratá-la a partir de ângulos originais. Sugere-se que os paradoxos deste olhar erótico, por assim dizer, do autor de Feuilleton, que foi considerado como gênero judaico por excelência, é indissociável das ambiguidades inerentes ao processo de emancipação judaica e, sobretudo, da assimilação judaica à cultura alemã.
\end{abstract}

Palavras-chave: Feuilleton. Flâneur. Neo-paganismo. Literatura judaica.

\begin{abstract}
This article discusses the Feuilleton as a specific Jewish genre of turn-of-the-century European Literature. The articulation between this kind of short story, which was an integral part of newspapers and magazines, and the social condition of Jewish writers, who had recently arrived to European metropolises from their hamlets and ghettoes, and who simultaneously belonged and did not belog to the urban scenery they portray, explains, as I argue, the originality of the viewpoints adopted by the Feuilletonists. They are understood as being influenced by a kind of « Jewish sight », marked by multiple points of view, typical of those who are, at the same time, insiders and outsiders, and expressed by the absolute freedom of movement of their subjectivity. The paradoxes of what could be called the erotic sight of the Feuilletonists is inextricably linked to the paradoxes of Jewish emancipation and Jewish assimilation to German culture..
\end{abstract}

Keywords: Feuilleton. Flaneur. Neo-paganism. Jewish Literature.

Que a arte de flanar foi um dia uma arte judaica é algo que a maior parte das pessoas já esqueceu em nossos dias. E, no entanto, este flanar judaico já não era o flanar em sua forma clássica, pois um dos pressupostos da flânerie é, justamente, o fato de que não se flana com algum propósito. Ao contrário: nada poderia ser mais avesso ao flanar do que a existência de algum propósito ao flanar, uma vez que flanar é, na definição de Stéphane Hessel, deambular pela "ilha da ausência de intenções" (HESSEL, 2011, p. 14).

Talvez seja possível dizer, igualmente, que não haja nada mais avesso ao judaísmo do que a ausência de intenções e propósitos: os preceitos da tradição judaica, expressos na Torá e exaustivamente discutidos por linhagens imensas de comentadores que atravessam muitos séculos, partem do pressuposto de que nada se faz sem uma intenção, de que a intenção é a razão de ser de cada ação que se faz ou que se deixa de fazer, e de que, além disso, uma ação só pode ser considerada juntamente com a intenção que a acompanha.

Tampouco é compatível com a tradição cultural do judaísmo, especialmente a do judaísmo europeu, a solidão ociosa e desconectada de qualquer propósito, que é o pressuposto obrigatório para a verdadeira flânerie. Em primeiro lugar, porque a cultura judaica tradicional não é uma cultura que privilegia a subjetividade e o particularismo de um indivíduo, que olha para o mundo à sua volta como se dele não fizesse parte: ao contrário, os preceitos judaicos propõem um engajamento permanente em questões que dizem respeito não ao indivíduo em si mesmo, mas ao indivíduo enquanto parte de um organismo social integral, inserido em sua comunidade, fora do

\footnotetext{
*Professor Livre-Docente de Literatura Hebraica e Judaica da Universidade de São Paulo. E-mail: 〈lkrausz@usp.br>.
} 
qual sua existência não possui significado algum. E, em segundo lugar, porque a cultura judaica tradicional enfatiza a identidade de um grupo, de uma coletividade, e não o individualismo lírico, sem o qual não é possível sequer pensar em flânerie.

O individualismo judaico, assim, e com ele o gosto judaico por certo tipo de flânerie, são fenômenos vinculados à emancipação judaica do século XIX. Da mesma forma, o que se poderia denominar de edenização da cidade moderna é também um fruto do século XIX. Pois na metrópole do século XIX anunciam-se, aos olhos do flâneur, miríades de objetos, de pessoas e de situações que são capazes de despertar sua curiosidade, de estimular sua imaginação, e de leva-lo a abstrairse da condição de habitante da cidade grande para contemplar essa mesma cidade de maneira lírica, como se fosse, por assim dizer, a partir de um ponto de vista externo, isto é, como se fizesse e não fizesse parte dela, simultaneamente. E como se a existência nada mais fosse do que um longo e lindo passeio por paisagens sempre novas, sempre intrigantes, sempre estimulantes: um jogo sem fim de luzes e de sombras.

É com Baudelaire que Paris se torna, pela primeira vez, assunto de poesia lírica: Baudelaire flana pela Paris do fim do século XIX e, como quem circula por uma espécie de jardim ao mesmo tempo maldito e encantado, ali encontra uma fonte aparentemente inesgotável de inspiração poética. Assim, Baudelaire acaba por encontrar um propósito em sua flânerie: transforma-a em poesia, e assim, também, inaugura uma outra uma flânerie: aquela cuja intenção poética vai além da simples contemplação para se tornar produção.

É o que fizeram, também, muitos flâneurs judeus, que se tornaram literatos num gênero que foi, em seu tempo, considerado um gênero judaico: o Feuilleton.

Walter Benjamin afirma, sobre a arte de Baudelaire: "não se trata de uma arte local: antes, o olhar que aí se lança sobre a cidade é o olhar de um alegorista; é o olhar de um estranho. É o olhar de um flâneur, cuja forma de vida ainda envolve com certo lustro conciliador a desconsolada forma de vida do homem da cidade grande, que está por chegar" (BENJAMIN, 1977, p. 179). E: "Ele ainda se encontra no limiar, tanto da cidade grande quanto da classe burguesa. Nenhuma das duas ainda o avassalou. Em nenhuma delas ele se sente em casa" (BENJAMIN, 1977, p. 179).

Esta situação liminar, de quem está inserido na lógica e na fisionomia da metrópole, mas, ao mesmo tempo, (ainda) é capaz de contemplá-la com os olhos de um outro, um forasteiro e um estranho, a qual, segundo Benjamin, Baudelaire ocupou e partir da qual foi o primeiro a dar expressão literária, ou seja, a partir da qual foi o primeiro a produzir literatura, é também a situação do recém-chegado: aquele cujo olhar ainda não foi devidamente anestesiado pelas rotinas urbanas; aquele capaz de reconhecer ângulos da cidade que já não são mais percebidos (ou que ainda não são percebidos) na rotina daqueles que, não sendo flâneurs, são simples passantes.

O lugar da flânerie é a passagem; a galeria coberta e envidraçada, em cujo interior o consumo de luxo ostenta seus prêmios mesmerizantes ante o olhar de quem passa. Ainda que o flâneur não seja o passante, ele parece ter um gosto todo especial por observar e descrever esta figura que é, por definição, parte integrante e inconsciente da paisagem local, e pode ser visto nas passagens, sempre de olho em algo: o passante é o Einheimische: aquele cujo lar se encontra firmemente estabelecido no coração da cidade. Aquele que opera algum dos importantes mecanismos que põem em marcha a vida da cidade. $O$ passante não é um forasteiro. $O$ passante jamais tem tempo para olhar para seja lá o que for com os olhos de um forasteiro. Ele tem seus olhos: um par de olhos. Que olham, sempre, da mesma maneira para tudo o que olham. Ele sabe o que quer e ele sabe porque ele vê. O olhar do alheio é-lhe tão desconhecido quanto o próprio alheio. O passante é uma figura da objetividade. Ele age com base em fatos. E, sobretudo, com base em cifras. Quanto ao flâneur, ele é uma figura da subjetividade. Age com base em impressões. Olha para o que vê com alguma incredulidade; com alguma dúvida. E, sobretudo, com base em sua própria imaginação. 
O passante é um homem de opinião.

É, também, um nacionalista que, ao contrário do flâneur, sabe qual é a sua nação; a sua cidade; a sua língua; o seu bairro; a sua casa.

Entre os recém-chegados à metrópole europeia do século XIX, vindos dos campos e das aldeias e das cidadezinhas interioranas, estão, também, os recém-emancipados: judeus que, ainda poucos anos antes, deixaram para trás os confins das aldeias e os muros dos guetos, que ruíram, na Europa Ocidental e na Europa de língua alemã, a partir das guerras napoleônicas. E esses egressos de guetos e de aldeias ainda em grande parte imersos num estilo de vida que pouco se havia alterado desde a Idade Média, chegam ao século XIX equipados com uma pesada bagagem cultural da qual, a partir de então, muitos tentarão se desvencilhar. E, de fato, o fizeram, com maior ou com menor sucesso.

Os mais notáveis flâneurs de quem se tem notícia na história da literatura de Feuilleton europeia, particularmente naquela do Feuilleton de língua alemã, foram judeus.

Pois esses escritores e Feuilletonisten judeus de língua alemã fizeram da flânerie uma arte toda especial: elevaram-na, por assim dizer, ao estatuto de prosa literária de primeira categoria, tanto na forma dos Feuilletons propriamente ditos quanto na forma de certos romances modernistas que são, estruturalmente, aparentados aos Feuilletons pois são construídos da mesma forma, isto é, em forma da flânerie.

Para eles, assim como para Baudelaire, a flânerie, em vez se ser uma atividade sem propósitos ulteriores, isto é, uma atividade que supostamente se esgotaria em si mesma, se torna uma forma de alta literatura que pressupõe a singular capacidade de conciliar a atenção com o nãoenvolvimento; a curiosidade com o distanciamento; a empatia com a indiferença.

No Feuilleton, a flânerie se cristaliza e ganha forma, sem nunca deixar de ser o que é, ou seja, sem nunca deixar de ser flânerie: o Feuilleton é, assim, uma espécie de milagre da emancipação judaica, e a emancipação judaica, como se sabe, caracterizou-se, desde sempre, por reconciliar coisas que são, por definição, irreconciliáveis: nacionalismo e cosmopolitismo; pertencimento e não-pertencimento; inclusão e exclusão.

Conciliar o irreconciliável é um fundamento, talvez o verdadeiro fundamento, das identidades hifenizadas características da situação liminar dos "alemães de fé mosaica"; dos "austríacos de religião israelita"; dos franceses de "origem judaica" e de outras figuras como essas, que habitaram o imaginário judaico e as cidades europeias do fim do século XIX e das primeiras décadas do século XX.

O flâneur não poderia prescindir desse olhar estrangeiro.

Que este tipo de olhar guarda analogias evidentes com o olhar psicanalítico concebido por Sigmund Freud é evidente: de alguma maneira, o flâneur, que inscreve o cenário urbano em seu texto narrativo, se torna uma figura análoga à do psicanalista, que inscreve a vida psíquica de seu paciente num texto narrativo. Ainda que um se volte sobre o fenômeno sempre renovado da vida urbana e o outro se volte sobre o fenômeno sempre renovado da subjetividade do indivíduo que se submete à análise, ambos fazem, de certa maneira, a mesma coisa: olham para o que olham a partir de novos ponto de vista.

O Feuilleton é hoje um gênero praticamente esquecido, mas foi, em seu tempo, uma faceta importante e extremamente popular dos jornais do século XIX e do início do século XX. Das suas características, a que mais salta à vista é, justamente, a de olhar para o que passa por normal como se fosse anormal (ou de olhar para o que passa por anormal como se fosse normal) e, assim, revelar dimensões insuspeitadas do óbvio. 
É nesse sentido que a arte do Feuilleton é uma arte do limiar e é neste sentido que a arte do Feuilleton é, também, uma arte judaica: se há algo de que o Feuilleton não pode prescindir, este algo é o olhar, um tipo de olhar que se situa exatamente sobre a fronteira que separa a presença da ausência e a distância da proximidade.

Enquanto literatura urbana e enquanto jornalismo urbano, o Feuilleton abrigava discussões políticas e sociais, mas foi sobretudo como o território no qual se plasmou um novo tipo de consciência, condicionada pelas realidades da vida urbana, que ele se popularizou enormemente, a ponto de se tornar parte indispensável dos jornais do fim do século XIX e do início do século XX: uma espécie de contraponto suculento, interessante, sedutor, criativo, à aridez do noticiário diário: um espaço para o livre movimento da subjetividade, em meio a um contexto primordialmente dominado pela objetividade (ou suposta objetividade). Um texto jornalístico destinado não a informar o leitor, mas destinado a formar o leitor: a dirigir seu olhar e a conduzir seu entendimento; a moldá-lo como habitante da metrópole; a transformá-lo por completo ao transformar seus pontos de vista.

Referindo-se ao Feuilleton, o Feuilletonist Joseph Roth escreveu:

O Feuilleton é tão importante para o jornal quanto a política, e é ainda mais importante do que a política para o leitor. O jornal moderno quer ser plasmado por tudo o que não seja a política. O jornal moderno precisa do repórter mais do que do artigo de fundo. Eu não sou um número extra. Não sou a sobremesa, e sim o prato principal... É a mim que se lê com interesse. Não aos relatos do que se passou no Parlamento, não aos telegramas. Eu não faço glosas bem-humoradas. Eu retrato a face do tempo. Esta é a tarefa de um grande jornal. (BIENERT, 2003, p. 15)

Segundo Alberto Dines (DINES, 2006, p. 182), Joseph Roth jamais se apresentava como jornalista, e sim como Dichter. E se é usual traduzir Dichter ao português por poeta, esta tradução é parcial ou totalmente equivocada: Dichter vem do alemão dichten, que significa criar textos em prosa ou verso, textos de ficção (como fica evidente, por exemplo, por meio da contraposição que Goethe faz, no título de seu livro de memórias, Dichtung und Wahrheit, ou seja, Ficção e verdade). Porque, para Roth, que se refere a seus Feuilletons como Dichtung, o bom Feuilleton nunca busca representar caninamente a realidade que, supostamente, seria objetiva - e Roth foi, de fato, alguém que considerava a objetividade como uma grande patifaria (DINES, 2006, p. 197). Talvez a maior de todas as patifarias.

Joseph Roth foi, como Dichter e como Feuilletonist, alguém que buscou interpretar o mundo, ler o mundo para oferecer ao leitor pontos de vista subjetivos, particulares, que se contrapunham aos rotineiros, consagrados e, principalmente, inconscientes: o Dichter recria e reconfigura a realidade no mesmo espírito do dito talmúdico segundo o qual não enxergamos o mundo tal qual ele é, mas sim tais e quais nós somos.

Dichten significa, ao mesmo tempo, adensar, ou condensar, mas a ideia de hermetismo, como em algo que é hermeticamente fechado, também faz parte do campo semântico constelado por este verbo.

No Feuilleton, assim como no Talmude, tudo é questão de ponto de vista e a diversidade de pontos de vista é, no Feuilleton tanto quanto no Talmude, como um conjunto de satélites que gravitam, cada qual em órbita própria, em torno de uma verdade, $a$ verdade, cuja presença se encontra no Makom - e o Makom, por suposto, não é alcançável para o ser humano.

Portanto, como afirma Roth, a objetividade, de fato, não passa de uma grande patifaria. 
As constelações de todos os tipos, de todos os tempos e de todos os tamanhos que se encontram no Talmude desdobram-se, igualmente, naquela atividade tradicional que, da Idade Média até o alvorecer da Era da Emancipação, e ainda além, pois ainda em parte o é, foi o ganhapão dos judeus: o comércio.

O comércio depende, por suposto, de um olhar capaz de distinguir coisas que são ignoradas pelos outros. E isto diz respeito a comércios de todos os tipos e de todas as dimensões: desde um colossal empreendimento ultramarino como a Companhia das Índias Orientais holandesa (V. O. C.) que foi, como se sabe, nos séculos XVII e XVIII em grande parte financiada e também dirigida por capitalistas judeus de origem portuguesa radicados nos Países Baixos, até o comércio ínfimo dos mascates judeus que, por séculos e séculos, desde a Idade Média, perambularam por todas as regiões da Europa Central e da Europa Oriental, comprando aqui peles de coelho para mais adiante trocá-las por moedas de prata, que, por sua vez, eram trocadas por pentes, que, por sua vez, eram trocados por batatas, que por sua vez eram trocadas por? Depende. Depende do que se apresentasse aos olhos.

Depende do que pudesse ser vislumbrado naquele instante em que é como se a luz do Messias estivesse lançando uma faísca de sorte e de oportunidade que, no entanto, só alguns olhos são capazes de ver.

Essa é a essência do comércio: o olhar adequado no momento adequado.

E essa é, também, a essência do Feuilleton: o olhar adequado no momento adequado.

Pois, quem tem o ponto de vista adequado é capaz de enxergar a face do tempo.

A “objetividade" que é produzida, comercializada e transformada em verdade, é produzida nas redações dos jornais.

Nas redações dos jornais de língua alemã, jornalistas judeus não eram presenças bemquistas.

Se isto é verdade para o que se passava na imprensa de língua alemã, desde os anos 1860 até 1938, continuou a ser verdade depois de 1945.

Em seu livro de memórias Mein Leben, Marcel Reich-Ranicki constata que, depois de 1945, jornalistas judeus tampouco eram presenças bem-quistas em redações de jornais alemães.

Reich-Ranicki descreve seu encontro com o chefe da seção de Feuilleton do jornal hamburguês Welt, na década de 1950:

Na redação do Welt (...) falei com o chefe da seção de Feuilleton, Georg Ramseger, um homem esbelto, delgado, que gostava de ser reconhecido como antigo oficial do exército. Ele tinha sido oficial da reserva. Em minha lembrança ele permanece, sobretudo, como um grande delator. Ele ouviu o que eu tinha a dizer e se levantou, tomando uma postura ereta. Depois de uma meia-volta com alusões militares ele abriu, com um gesto teatral, o armário que estava às suas costas e agarrou, aleatoriamente - de qualquer maneira, ele queria despertar esta impressão - alguns livros. Eram cinco ou seis romances, todos eles de autores leste-europeus - e isto, evidentemente, não poderia ser um acaso. Alcançou-os a mim, não sem certa solenidade. E então, com uma voz áspera e num tom que lembrava o que se ouve em lounges de oficiais, disse: "Escreva sobre esses livros. $\mathrm{Se}$ as críticas forem boas, nós as publicaremos. Se forem ruins, não as publicaremos. Isto é tudo o que eu posso fazer pelo senhor. (REICH-RANICKI, 2000, p. 398).

Relata, igualmente, seu encontro com o redator de literatura da Frankfurter allgemeine Zeitung, para lhe oferecer algo que o deixou boquiaberto: resenhas sobre livros publicados na Alemanha Oriental, um tema então completamente ignorado pelo jornal: "Sieburg ficou atônito. 
Se eu tivesse ousado comentar que na Frankfurter allgemeine ninguém dava atenção à lírica mongólica e nem à dramaturgia búlgara - dificilmente sua admiração teria sido maior." (REICHRANICKI, 2000, p. 398).

Seja como for, se a objetividade é produzida nas redações, o Feuilleton, era (ainda que não seja mais) produzido nos cafés e, em geral, consumido, também, nos cafés.

Os cafés são um "terceiro espaço" (Thirdspace) na terminologia de Homi Bhabha: um lugar no limiar; um lugar entre lugares, para além da dicotomia entre o espaço "real" e o "imaginário". Um lugar para identificações híbridas e para diálogos entre línguas diferentes. Um lugar de tradução, por suposto, e de passagem. Um lugar de fronteira que, no entanto, é menos um lugar onde se demarcam limites do que um lugar onde se dão os encontros. É o lugar do sincretismo por excelência. "Escritores judeus gravitavam nesses cafés literários de cidades europeias, que se tornaram substitutos de um lar, de uma comunidade, ou das casas de estudos tradicionais, por eles deixadas para trás. Nesses cafés literários, eles trabalhavam, escreviam, se encontravam e trocavam ideias..." (PINSKER, 2011, p. 37).

O café nunca foi um lugar "puro" e o café foi sempre um lugar de transcendência do especificamente local: um lugar que pode, por exemplo, ser judaico e não judaico ao mesmo tempo. O café foi o lugar onde se produziam os Feuilletons e a subjetividade dos Feuilletons. Um lugar sincrético tanto quanto o Feuilleton que nele se produz - e que nele se consome, ainda que o jornal se coloque, por assim dizer, entre o produtor e o consumidor que, não obstante, podem estar sentados lado a lado, no mesmo café.

O café é, sobretudo, um lugar na fronteira: entre um lar perdido e um lar ainda por ser conquistado; entre o dentro e o fora; entre o local e o importado; entre o heimlich e o unheimlich. E o flâneur encontra, no café, uma espécie de Ersatz, provisório, evidentemente, de um lar, já que o flâneur é também um Grenzgänger, uma criatura das fronteiras, que as atravessa, constantemente, de um lado para outro, como o sinistro Kapturak, personagem sempre idêntico a si mesmo, que aparece em tantos contos, novelas e romances de Joseph Roth, e cujas atividades envolvem sempre coisas como jogos de azar nos quais grandes somas de dinheiro mudam de mãos; contrabando de pessoas e de coisas de um lado para outro da fronteira; agiotagem; diversos tipos de agenciamentos dúbios; espionagem.

Se o café não é o lugar por excelência da flânerie propriamente dita, é o lugar no qual se reflete sobre o flânerie - seja a própria, seja a de alguém outro: o autor do Feuilleton que, justamente, está sendo lido no café, e que, justamente, está sendo escrito no café.

Quanto a Joseph Roth, ele teria dito, de si mesmo: "sou um Caféhausnationalist: um nacionalista do café."

Assim, toda uma parte do jornal, a que observa a face do tempo, se faz de subjetividade e de originalidade e resulta do trabalho do Dichter, que pertence ao café, cujo lugar de origem é o café e cujo destino é, igualmente: o café.

O comentário colateral é o discurso do café: é uma espécie de nota à margem.

Manfred Herbst, o protagonista de Shira, de S. Y. Agnon, é um historiador da Universidade Hebraica de Jerusalém e é, também, um judeu alemão que, estando em Jerusalém na década de 1930, e vivendo, como convém a um intelectual judeu-alemão, no bairro de Rehavia, não abriu mão do hábito europeu da flânerie. Ele flana pelas ruas e pelos bairros de Jerusalém e ele flana, igualmente, pelas fontes históricas das quais se serve em seu trabalho como historiador, no qual se dedica a investigar os costumes funerários do Império Bizantino. Ele flana pela cidade e se envolve num caso extraconjugal com a enfermeira russa Shira. Ele flana pelas suas fontes históricas e não chega a parte alguma. Seu livro sobre os costumes funerários no Império Bizantino atravessa os anos como um projeto irrealizado. 
Assim como Goethe, Manfred Herbst despreza o café, que considera como um veneno, mas aprecia o chá.

A opacidade do café e a escuridão do café se opõem à transparência do chá.

A opacidade implica em ocultação e em separação enquanto a transparência representa, sempre, algum tipo de promiscuidade.

Se o chá é uma espécie de véu translúcido, o café é uma cortina escura e espessa, como são espessas e escuras as cortinas de veludo que muitos cafés vienenses têm bem à frente de suas portas de entrada, que separam o interior do café do mundo exterior.

O café escuro é como um manto escuro e grosso e é como o casaco escuro e grosso que separa o protagonista do romance Hóspede por uma noite, de S. Y. Agnon, do seu entorno, enquanto ele flana pelas ruas do inverno de sua cidadezinha natal, Schibusch, depois de décadas de ausência, encontrando-a arruinada pela I Guerra Mundial.

Este protagonista dá a este grosso casaco o nome de aderet. Aderet é o termo bíblico que designa os mantos dos reis. Enquanto isto, os demais moradores da cidadezinha perambulam por Schibusch com roupas furadas que deixam à mostra partes de suas carnes.

Sobre o café, o rabino Shimon Deutsch afirmou:

"Creio que, se nossos sábios tivessem conhecido o café, teriam instituído uma brachá especial".

"E por que o café? O chá também, não? Tem um efeito semelhante..."

"Não é a mesma coisa, porque o chá é translúcido e o café é opaco." eclético.

Seja como for, o Feuilleton conjuga a opacidade e a transparência: é sincrético e é também

Nele, há lugar para tudo, como nos fardos que velhos mascates judeus carregaram nas costas, por séculos e por séculos, em suas intermináveis deambulações pela Medine, que era como se chamava a terra em que viviam em seus exílios e carregavam, igualmente, os fardos dos seus exílios, naquele velho alemão judaico da Morávia e da Boêmia, o jüdisch-deutsch, hoje totalmente esquecido (ao qual, porém, alguns idichistas com grande condescendência alguma vez chegaram a dar o nome de ídiche ocidental).

No conto Der Dorfgeher, do escritor judeu boêmio de Münchengrätz, de língua alemã, Leopold Kompert (1822-1886), que é uma espécie de história do filho pródigo ambientada no interior da Boêmia do século XIX, um jovem judeu, que deixou para trás o mundo dos pais e se habituou à vida vienense, retorna, incógnito, disfarçado de mendigo, de Schnorrer, à casa de sua família, para contemplar um mundo que se tornou "desfamiliar" ou unheimlich aos seus olhos (um lar que não é mais um lar, ainda que tampouco haja, para ele, verdadeiramente, algum novo lar que o substitua).

Leopold Kompert nos apresenta, nesse conto, a um mascate assim: é Schimme Prager (HÖFLER e SPÖRK, 2000, p. 10), o Dorfgeher, isto é, o que perambula de aldeia a aldeia, de domingo a sexta feira, com seu grande fardo; que retorna à aldeia para passar o Shabat com a família, e que é o pai do filho pródigo.

A situação do filho do mascate judeu, para quem o mundo da origem já não é mais aceitável em sua estreiteza e em sua estagnação, e para quem, ao mesmo tempo, um novo lar não é algo de que ele possa dizer que encontrou, é também uma situação na fronteira e no limiar: ele é um paradigma do homem que vive entre dois mundos, que está sentado entre duas cadeiras.

E quem está sentado entre duas cadeiras, como se sabe, não está de pé e tampouco está sentado.

A narrativa de Der Dorfgeher assinala uma mudança drástica na face do tempo: do último tempo no qual a última palavra é sempre a dos mais velhos para o primeiro tempo no qual essa mesma, que por óbvio já não é mais a mesma, será sempre dos mais novos.

Este é, também, o momento no qual o passado bíblico e o futuro messiânico passam a ser encobertos, eclipsados pelo poder do presente. 
Assim, o único lar verdadeiro do flâneur, ou do Grenzgänger, se é que pode existir algum, é, segundo afirmaram alguns, a língua.

Joseph Roth cedo percebeu e disse: "A pátria do verdadeiro escritor é sua língua." (KÖPPEN, 1996).

Se a língua é a única Heimat, a terra mãe original do verdadeiro Dichter, o Feuilleton é, assim como o café, uma espécie de lar - ainda que no mais das vezes apenas bem provisório - para essa língua.

A Berlim dos anos 1920 é o cenário dos melhores Feuilletons de Joseph Roth, que se mudou de Viena para a capital alemã ao fim da $1^{\text {a }}$. Guerra Mundial pois, se a Alemanha era, neste momento, um país arruinado, a Áustria, e Viena em particular, emergiram do conflito dupla e triplamente arruinadas: de capital de um império de 54 milhões de habitantes, Viena tornou-se a capital de uma república pobre e insignificante, habitada por pouco mais de 7 milhões de pessoas, das quais mais de $25 \%$ viviam no que um dia tinha sido uma grande metrópole europeia: a capital imperial, onde se passava fome ao final da guerra: uma cidade arruinada em meio aos escombros do sonho imperial natimorto de perenidade acalentado pelo finado Kaiser Franz Joseph.

É na Berlim do entre-guerras que o Feuilleton judeu-alemão alcança seu apogeu como gênero.

E Joseph Roth foi um dos mestres incontestes do Feuilleton berlinense.

"Joseph Roth não amava Berlim. Sua ligação com a cidade tinha um caráter puramente comercial", diz Michael BIENERT (2003, p. 13) em "Journalist in Berlin", ao descrever a meteórica trajetória que Roth percorreu na imprensa da República de Weimar.

Seja como for, Berlim tem grande importância topográfica e temática na obra de Joseph Roth, para quem o bom Feuilleton se resumia em "dizer coisas válidas em meia página" (BIENERT, 2003, p. 14).

Em seus textos, estão os elementos fundamentais do Feuilleton vienense: "o olhar subjetivo sobre aquilo que é aparentemente secundário e o prazer da arte da língua são transpostos para a forma moderna da reportagem literária (BIENERT, 2003, p. 15)."

Ainda que o prazer e a arte da língua tenham sido, por assim dizer, a substância da vida de Joseph Roth, o fato de ele ter afirmado, de maneira tão categórica, que "a pátria do verdadeiro escritor é sua língua" traduz não a certeza de que a língua alemã lhe pertencia e de que ele pertencia a ela, e sim uma incerteza a respeito de tais pertencimentos.

Se os judeus, e especialmente os escritores judeus, se empenharam, como mais ninguém no mundo em seu tempo, em assenhorar-se dessa língua alemã, em domesticá-la, em amá-la - a depender da origem, do talento e da sensibilidade de cada um - e se é verdade que, a certa altura, o alemão foi, de fato, uma língua judaica, é também evidente que, se o alemão era a língua de grande parte desses Dichter e Feuilletonisten judeus-alemães, raramente era sua língua-mãe - ou sua única língua mãe.

A quem tem certeza de que determinada língua lhe pertence, e de que pertence a determinada língua, jamais ocorreria fazer uma afirmação como essa feita por Joseph Roth: "A pátria do verdadeiro escritor é sua língua". Uma afirmação deste tipo sequer é concebível para quem tem certezas no que diz respeito à própria pátria e à própria língua. E se há assuntos a respeito dos quais não há e nem nunca houve, entre os judeus, qualquer tipo de certeza, então são esses: a pátria e a língua.

Consta que, já na década de 1930, tendo-se mudado para Paris, Joseph Roth esteve a ponto de começar uma nova carreira literária, em língua francesa (COETZEE. J. M., 2007, p. 110): “Ah, se eu pudesse escrever em francês! Agora, aos quase quarenta anos de idade, começo a entender que escrever em uma única língua é como ter apenas um braço. Tendo duas pátrias, eu deveria poder dominar duas línguas paternas. Mas estou velho! E a língua de um país é ainda mais difícil de se conhecer do que os seus habitantes (BRONSEN, 1974, p. 276)."

E isto nos leva a uma outra característica central da vida do café e a uma outra característica central da vida do Feuilleton: a necessidade de tradução. 
Pois, dentre os grandes autores do Feuilleton judaico-alemão, não há um de quem se possa dizer que tenha vindo de um ambiente linguístico puramente alemão, como aqueles monólitos nos quais nasceram determinados escritores que tinham, desde sempre e para sempre, o alemão e a Alemanha como referências únicas. Autores como, por exemplo, Ernst Jünger.

O húngaro, o polonês, mas, sobretudo, o ídiche e o hebraico: essas (às vezes também outras) línguas encontram-se, ainda que, em certos casos, só em forma de resíduos ou de escombros, impregnadas na consciência linguística de todos os grandes Feuilletonisten judeus de língua alemã.

Pois, essas outras línguas, por sua vez, têm raízes e essas raízes remontam diretamente não apenas ao texto bíblico mas, sobretudo, à cantilação pública do texto bíblico, que era, como se sabe, obrigatoriamente presenciada por todos, com sua musicalidade inesquecível, que determinava, de maneira definitiva, um tipo único, especial, possivelmente hereditário, de sensibilidade auditiva. E dessa se encontra, sempre, algum mesmo Klang, alguma mesma sonoridade, alguma mesma memória de música secreta ali, no texto do Feuilleton.

A grande importância da música judaica para os judeus teve sua derradeira expressão em certas orquestras de prisioneiros que tocavam música judaica para acalentar os que caminhavam em direção a grandes salas cimentadas, dicht, hermeticamente fechadas, que foram construídas na Polônia da década de 1940.

Como escreve Schachar Pinsker, ao longo das últimas décadas do século XIX e no início do século XX o Feuilleton tornou-se conhecido como um gênero literário e jornalístico judaico porque tantos e tantos autores de Feuilletons, em diversos idiomas (francês, alemão, russo, polonês, mas também em ídiche, hebraico e ladino) e em diversos países, eram judeus: "O Feuilleton (era) uma importante forma literária e jornalística na escrita russa, alemã, hebraica e ídiche daquele momento, que funcionava como um 'instantâneo' modernista, descrevendo o espaço urbano. (PINSKER, 2011, p. 80)"

E dentre esses tantos e grandes autores judeus de Feuilletons em tantos idiomas, em diferentes idiomas, se há uma característica comum, então essa é: a presença da música e a presença da tradução.

O flâneur, o autor de Feuilletons, é um forasteiro mais ou menos recém-chegado à cidade que ele se empenha em descrever. Sua língua mãe só muito poucas vezes é a língua na qual escreve seus Feuilletons, assim como o mundo que ele estava habituado a contemplar em sua infância também difere do mundo que ele contempla em seu trabalho como Feuilletonist.

No caso de Joseph Roth, passou-se, por óbvio, do ídiche ao alemão. E depois, como se sabe, ao menos em parte, ao francês.

Outro exemplo de flânerie literária judaica analisada por Pinsker diz respeito aos Feuilletons que Yossef Chaim Brenner escreveu à época em que, vivendo em Londres, editava a revista literária hebraica Ha-me'orer. A respeito de Brenner, Pinsker escreve: "Neste ensaio, escrito no gênero do Feuilleton (...) Brenner apresenta um breve e poderoso retrato da 'multidão' em contraposição à subjetividade individual do flâneur, o observador que perambula pela cidade. Ele destaca o choque provocado pelo barulho e pela rapidez dos bondes e pelas transformações do cenário, assim como uma articulação entre o sentido de alienação e de estranhamento (...), e (faz) uma projeção desse estranhamento sobre o espaço urbano (PINSKER, 2011, p. 80)."

É desnecessário dizer de Brenner que tampouco o hebraico era sua língua mãe.

E é preciso lembrar que o hebraico tampouco era a língua de Londres.

Escrever em Londres e em língua hebraica um Feuilleton que tem como tema o bairro judaico de Londres é uma tarefa que demanda múltiplas operações de tradução: da paisagem londrina para a língua hebraica, por suposto. Da língua ídiche dos judeus pobres do East End para o inglês pobre dessa região da cidade. Finalmente, desse barulhento amontoado de imigrantes judeus do Leste da Europa, que se acotovelam em meio a máquinas de todos os tipos, que parecem 
ameaça-los, o tempo todo, por todos os lados, não raro decepando-lhes membros inteiros ou mesmo a vida, para as alturas plácidas e celestiais da língua máxima: aquela cujas palavras, pronunciadas pela voz certa no momento certo, criaram o mundo e tudo o que nele se encontra.

Notável entre os autores de Feuilletons de seu tempo, anos antes de se dedicar à escrita de um livro como Der Judenstaat, a obra fundamental do sionismo político, foi Theodor Herzl, que descreveu uma carreira brilhante no grande jornal vienense Neue freie Presse, notabilizando-se pela qualidade de seus Feuilletons, naturalmente em língua alemã. Herzl era, como se sabe, judeu de Budapeste, isto é, vinha de um lar de língua húngara marcado pelas inflexões do ídiche. Em seus textos escritos num alemão cuja elegância era louvada e enaltecida à sua época, Herzl lançavam olhares irreverentes e muito originais sobre a vida vienense à época do apogeu da Monarquia Habsburga, com suas frivolidades e seus luxos, e também com seus abismos sociais, presentes, igualmente, na numerosa e influente comunidade judaica vienense, marcada pelas diferenças sociais, culturais e econômicas, em cujo seio estavam desde aristocratas portadores de títulos nobiliárquicos hereditários; grandes burgueses; profissionais liberais e funcionários até operários, prostitutas e todo tipo de indigente.

De fato, quando Herzl se lançou à promoção da causa do sionismo político, fê-lo, como afirma Edward Timms, "equipado com todos os implementos do perfeito folhetinista".

Herzl notabilizou-se por sua capacidade de retratar cenários complexos com apenas poucos traços e a lucidez de sua linguagem combinada com a variedade e a complexidade dos seus interesses conquistou-lhe leitores como Arthur Schnitzler e Stefan Zweig, sempre encantados pela inteligência irônica dos seus Feuilletons.

Um dos mais importantes romances alemães do século XX, Berlin Alexanderplatz, de Alfred Döblin, é um exemplo legítimo da flânerie literária.

Trata-se de um romance que tem como protagonista a metrópole, isto é, Berlim, vista pelos olhos de um personagem que começa sua trajetória com a inocência de um flâneur, mas que acaba triturado pela cidade: Franz Biberkopf, recentemente libertado do presídio de Tegel, deambula por Berlim e a contempla com esse olhar liminar que só o flâneur possui: esse olhar de quem pertence, mas não pertence, ao lugar onde se encontra.

Logo no início da narrativa, ao descer do bonde que o leva de Tegel até a região do Scheunenviertel, junto ao Alexanderplatz, que era o bairro no qual viviam judeus tradicionalistas, recém-chegados do Leste europeu, Franz Biberkopf se encontra com dois personagens que são, assim como ele mesmo, estranhos à realidade berlinense, e que ocupam, como ele mesmo, posições liminares. São dois Ostjuden. Eles se chamam Nahum e Elieser. Ao acolher o estranho, que acabam de encontrar no saguão do prédio em que vivem, Nahum apressa-se em lhe ensinar algo, como alguém que dá um remédio às pressas para algum moribundo. Sua maneira de lhe ensinar algo, como convém a alguém que vem do mundo hassídico galiciano, é contar-lhe uma parábola.

Esta, narrada às pressas, trata de certo Zannovich.

Zannovich é um judeu albanês que fez fortuna em Veneza, e cujo filho se faz passar por príncipe albanês, chegando a conquistar a proteção da Imperatriz Maria Teresa da Áustria, conhecida pelo ódio que tinha aos judeus. Neste ponto da história, Nahum é interrompido por Elieser: ele tem muita urgência em narrar o trágico desfecho da história do filho de Zanovich que, desmascarado, acaba por suicidar-se, cortando os próprios pulsos, num presídio em Bruxelas.

A seguir, seu corpo é levado junto com os cadáveres de gatos, cachorros e cavalos, e incinerado. 
Trata-se de uma parábola que diz respeito a Franz Biberkopf e que também diz respeito a recém-chegados com Nahum e Elieser: uma parábola que diz respeito às perspectivas da assimilação - a dos judeus tanto quanto a dos flâneurs.

Berlin Alexanderplatz é talvez o melhor dos retratos literários da capital alemã do período entre-guerras. Escrito segundo a cadência que os bondes elétricos, os semáforos e os automóveis impunham sobre os habitantes da cidade, segundo os ritmos dos matadouros, igualmente descritos no romance, nos quais se esquartejam, diariamente, vacas e as vitelas, o livro registra a soberania das máquinas, a força única que impera num estado cujas bases simbólicas imperiais ruíram sem que surgisse uma ordem constitucional suficientemente forte para sustentá-lo.

A integridade e a ingenuidade do flâneur não tarda a ser destruída pelas armadilhas que espreitam em toda a parte: a metrópole moderna é naturalmente hostil ao flâneur e à flânerie e é naturalmente hostil aos que a contemplam a partir do limiar.

Transforma-os de sujeitos em objetos.

E de objetos em cinzas, como se sabe.

Schachar PINSKER (2011, p. 98) aponta para o romance Chayei nissu'im de David Vogel (1891-1944), ambientado na decadente Viena dos anos 1920 como o romance urbano judaico por excelência e para Rudolf Gurdweil, o protagonista desse romance, como um dos exemplos máximos de flâneur, isto é, "protagonista ambulante" (touring protagonist) na literatura judaica do século XX: "Gurdweil é, provavelmente, o melhor exemplo que há, na ficção hebraica da primeira metade do século XX, do flâneur de Walter Benjamin. Para Benjamin, a rua se torna um lugar de moradia para o flâneur: ele está tão em casa em meio às fachadas das casas quanto um cidadão está em casa entre suas quatro paredes (PINSKER, 2011, p. 99)".

Quanto a Gurdweil, “ é, sem dúvida, um flâneur, um ambulante perpétuo, que não possui um lar verdadeiro, mas que constrói para si uma espécie de lar imaginário nas ruas de Viena." (PINSKER, 2011, p. 99). Ele é o flâneur em si mesmo, o flâneur que leva a flânerie às últimas consequências: a seus olhos a cidade se torna um território novo e desconhecido a ser interpretado, uma espécie de desafio para a inteligência; um enigma e um quebra-cabeças a ser decifrado. Gurdweil refrata a experiência urbana sobre a própria subjetividade e faz da paisagem urbana um espaço mental novo: "ele sai e perambula automaticamente, sem direção, sem qualquer tipo de propósito ou de destino específico. Sua deambulação é circular, como se ele estivesse caminhando por um imenso labirinto (PINSKER, 2011, p. 100)."

Não é por coincidência que, nesse romance, o café seja o ambiente no qual têm lugar os desdobramentos cruciais da narrativa. Nesses cafés descritos por Vogel, mundos apartados na geografia da cidade se tocam mutuamente: em nenhum outro lugar de Viena o casamento de Gurdweil com Thea - ele, um judeu recém-chegado de uma província russa; ela uma baronesa austríaca - seria imaginável.

Berlim é, também, a protagonista de um dos mais notáveis autores de Feuilleton das primeiras décadas do século XX: Franz Hessel (1880-1941). Como flâneur nas cidades que mais amava (ao lado de Berlim, também Munique e Paris), e como alguém que jamais se rendeu ao pensamento utilitarista e a qualquer tipo de visão objetiva da realidade, Hessel foi alguém que, como convém a um Dichter e autor de Feuilletons, voltou-se, o tempo todo, contra as fixações materialistas do seu tempo.

A realidade urbana, contemplada a partir do ponto de vista (ou dos pontos de vista) da liberdade transforma-se, assim, [para ele], numa espécie de bazar da felicidade, cuja mercadoria está inteiramente à disposição do olhar do escritor-flâneur (KILCHER, 2003, p. 237).” 
Hessel foi também amigo de Walter Benjamin, com quem traduziu ao alemão vários trechos de À la recherche du temps perdù, de Marcel Proust. Deixou a Alemanha somente em 1938, refugiando-se na França, primeiramente em Paris e, mais tarde em Sanary-sur-Mer. Depois da invasão da França, foi confinado ao campo de concentração de Les Milles, mas conseguiu retornar a Sanary em julho de 1940, onde morreu em janeiro de 1941.

Foi, especialmente, amigo do escritor francês Henri-Pierre Roché: ele figura, sob o nome Jules, juntamente com a escultora Helen Grund, que figura sob o nome Käthe, no romance de Roché intitulado Jules et Jim, de 1953, celebrizado em forma de filme por François Truffaut.

Um aspecto fundamental da flânerie, o erotismo, é o fulcro desse romance em que os movimentos do desejo empurram os personagens ao sabor de seus incontáveis caprichos, e os levam a descrever trajetórias erráticas mas, ao mesmo tempo, situadas, sempre, sob a égide tão encantadora quanto irresistível de Eros.

Que o movimento ad libidum é o fundamento da flânerie e, com ela, também do Feuilleton é a verdade que subjaz a um gênero cuja gênese está da entrega ao erotismo - por óbvio não (necessariamente) de caráter sexual, mas aquele tipo de erotismo que Stendhal chamou de l'amourgôut.

Segundo Léon BLUM (1947, p. 146) o amour-gôut é o amor autoconsciente, sempre moderado por uma dose suficiente de ironia, para que nunca se transforme em paixão: é o erotismo próprio do flâneur, em permanente movimento, como está sempre em movimento a vida psíquica, que ama o amor em si mesmo mais do que qualquer objeto do amor.

É por amarem o amor mais do que ninguém e é por quererem manter vivo esse amor pelo amor mais do que qualquer outra coisa que os personagens de Jules et Jim não param de criar novas e intrigantes configurações amorosas, que não têm como propósito algum tipo de situação duradoura, e com ela o fim do amor, mas, antes, pretendem preservar o chamado da vida amorosa.

Segundo Käthe, para que se mantenha Eros vivo, é preciso "começar do zero e reinventar as regras, correndo riscos e pagando à vista (ROCHÉ, 2006, p. 76)". É assim que os cúmplices de um triângulo amoroso conservam o entendimento perfeito e a alegria: forçados a se conformarem aos constrangimentos legais, eles "estavam envergonhados por obedecerem às leis, e não à lei que carregavam dentro de si."

Käthe lê em voz alta, para seu marido e para seu amante, uma passagem de As afinidades eletivas de Goethe (ROCHÉ, 2006, p. 94) que é, como nenhum outro, o romance que propõe a subjetividade livre, a independência e a autonomia de um indivíduo, que é feito de desejos, que é movido por desejos, como o fundamento daquela mesma crença nas relações livres entre o homem e a sublimidade que atravessa a cultura do humanismo alemão oitocentista - e que encontra, no erotismo itinerante do Feuilleton tanto quanto na flânerie, amorosa ou não, formas possíveis de expressão.

Paris, a "capital do século XIX" segundo Walter Benjamin, é o lugar onde desponta esta forma de erotismo urbano, que pode se voltar para qualquer um dos múltiplos aspectos da vida na cidade grande. Como, por exemplo, as demolições, por meio das quais se abre espaço, o tempo todo, para o novo, reiteradas vezes focalizadas por Eugène Atget, o precursor da fotografia feuilletonística.

E de Paris este tipo de olhar se irradia para outras metrópoles europeias, como Viena e Berlim, nas quais a expansão do capital também impõe rápidas transformações à paisagem urbana, em permanente renovação em meio aos escombros das demolições.

A infindável deambulação, sobre a qual não paira sombra de escatologia é o fundamento de determinada visão de mundo que, emancipada de ideias religiosas sedimentadas pelos séculos, estabelece a supremacia da subjetividade e, com isso, o retorno a uma espécie de paganismo - que é o tema de Der alte Westen (O velho Oeste) (HESSEL, 2011, p. 129) - um dos pontos culminantes da sua escrita feuilletonística de Hessel. Aqui, ele narra um passeio por aquela região berlinense entre Schöneberg e o Tiergarten, que hoje é o centro do consumismo berlinense, mas que, um dia, era conhecido como o alter Westen, onde residiu aquela burguesia bem estabelecida que, a partir 
da virada do século, mudou-se para localidades como Dahlem, Westend e Grünewald, deixando para trás o século XIX e entregando ao declínio velhos apartamentos em estilo eclético, com seus Berliner Zimmer cujas janelas se abriam para pátios sombrios.

Como se estivesse caminhando em meio às ruínas de uma civilização desaparecida, sepultada pela fuligem do tráfego de automóveis e de caminhões que tomou conta do velho bairro, Hessel busca, nas ruas tanto quanto em sua memória, os últimos remanescentes do que ele chama de preussisches Griechenwesen, isto é, do helenismo prussiano, na forma de esculturas de Apolo, em bronze; de bustos de Afrodite, em mármore; de frisas nas quais estão relevos que representam Flora e Hebe; de esculturas de Musas que enfeitam velhos jardins, hoje tomados por ervas daninhas. Até mesmo no interior da grande sala as Filarmônica de Berlim, o órgão é flanqueado, de ambos os lados, por orgulhosas cariátides, que portam liras em suas mãos.

Acima delas, pairam anjos cristãos, cujos olhares bondosos se voltam sobre o público.

"Nós, porém, permanecemos fiéis às distantes mulheres pagãs", conclui Hessel.

\section{Referências}

BENJAMIN, W. Illiminationen. Frankfurt a. M: Suhrkamp, 1977.

BIENERT, M. Joseph Roth in Berlin. Colônia: Kiepenheuer und Witsch, 2003.

BLUM, L. Blum, Stendhal et le Beylisme. Paris : Albin Michel, 1947.

BRONSEN, D. Joseph Roth: eine Biographie. Colônia: Kiepenheuer \& Witsch, 1974.

DINES, Alberto. "Posfácio: escritor aceso, jornalista ligado" em ROTH, J. Berlim. São Paulo: Cia. das Letras, 2006.

HESSEL, F. Spazieren in Berlin. Berlim: Verlag für Berlin-Brandenburg, 2011.

HÖFLER, G.; SPÖRK, I. (eds.) Der Dorfgeher - Ghettogeschichten aus Alt-Österreich. Leipzig: Reclam, 1997.

KILCHER, A. Lexikon der deutsch-jüdischen Literatur. Frankfurt a. M: Suhrkamp, 2003.

KÖPPEN, W. Im Kampf für ein bürgeriches Vorurteil. Disponível em: <https://www.deutscheakademie.de/de/auszeichnungen/georg-buechner-preis/hermann-

kesten/laudatio>, 1996. Acesso em: 25.11.2020.

PINSKER, S. Literary Passaports - The Making of Modernist Hebrew Fiction in Europe. Stanford: Stanford University Press, 2011.

REICH-RANICKI, M. Mein Leben. Stuttgart: DTV, 2000.

ROCHÉ, H. P. Jules e Jim. Rio de Janeiro: Zahar, 2006. 